\title{
Life Balance of Russian Students (by the Example of Students of the Finance Department of Plekhanov Russian University of Economics)
}

\author{
Andrey Koshkin ${ }^{1}$, Kseniya Katusheva ${ }^{1}$, Alexey Bolvachev ${ }^{2} \&$ Irina Yablochkina $^{3}$ \\ ${ }^{1}$ Chair of Political Science and Sociology, Plekhanov Russian University of Economics, Moscow, Russian \\ Federation \\ ${ }^{2}$ Finance Department, Plekhanov Russian University of Economics, Moscow, Russian Federation \\ ${ }^{3}$ Center for Humanitarian Training, Plekhanov Russian University of Economics, Moscow, Russian Federation \\ Correspondence: Andrey Koshkin, Chair of Political Science and Sociology, Plekhanov Russian University of \\ Economics, Stremyanny per. 36, Moscow, 117997, Russian Federation. Tel: 7-495-958-2327. E-mail: \\ kafedra_polit@mail.ru
}

Received: September 24, 2014 Accepted: October 22, 2014 Online Published: November 15, 2014

doi:10.5539/res.v6n4p182

URL: http://dx.doi.org/10.5539/res.v6n4p182

\begin{abstract}
Students have to optimize their life balance in order to get pleasure from life. Unfortunately, not all young people can cope with this difficult but important process efficiently. From the perspective of personal satisfaction and public recognition in studies, at work, and in everyday life students sometimes feel life imbalance which has a strong negative impact on their personal and professional development.

The article reveals the peculiarities of students' life balance formation under conditions of their intensive activity in studies, at work, and in everyday life. In studies the students' balance between their personal assessment of acquired knowledge, the nature of teaching, material rewards, etc. and public recognition by other students, professors, university administration, etc. is defined. At work the students' balance between their personal satisfaction from the obtaining financial independence, acquiring professional skills, benefiting family, etc. and public recognition of these students by colleagues, administration, family, classmates, professors, etc. is revealed. In everyday life the students' balance between their personal satisfaction from the creating comfortable living conditions, formation of the basics of modern everyday lifestyle, etc. and their public recognition by hostel administration, roommates, friends, relatives, etc. is described.
\end{abstract}

Keywords: everyday life, life balance, students, study, personal satisfaction, public recognition, work

\section{Introduction}

As a rule, Russian students are not quite sure that they properly balance efforts on various activities in life. At the same time, to get a pleasure of life a person must have an integrated balanced lifeload (Shanafelt, 2005). As a result, we formulated the following scientific hypothesis: a successfully-developed ability of Russian students to optimize the time and efforts in key areas such as study, work, and everyday life focusing on personal satisfaction and public recognition eventually leads to the establishment of their efficient life balance.

However, a relatively small number of students feel the confidence that they establish effective life balance, and many even find it difficult to describe the level of their life balance. In other words, the majority of students do not have experience in organization of life balance or their experience is brief.

Meanwhile, students can and must cope with question of optimizing life balance. For that purpose, it is necessary to analyze the features of life balance formation in details, then to identify ways of its optimization, and later to promote the results of the research widely among the student community, professors and administration of the high school. However, the main limiter of creation of effective student life balance is the fact that this issue is still neglected in the modern Russian science. Therefore, nowadays it is extremely important to accumulate objective research material in order to develop correct and clear recommendations for Russian students and professors.

Generally, the problem of life balance is embodied in the theoretical writings of Western scholars. To a large extent our research is an addition to the concept of M. Frisch, who considers that the life satisfaction of people is 
formed in accordance with their needs, goals, and expectations in the most important areas of life that are satisfied (from employment and training activities to the game) (Frisch , 2005).

We suppose that students have different learning abilities, and this affects their ability to achieve a balance in studies. It is necessary to focus on the opportunities, needs, and expectations of students, and in this regard our approaches have a number of points in common with the theory of M. Buckingham. We found the author's position interesting and tried to develop it. The authors' position is that no need to invest in people more than they possess, and to achieve true success in life it is just necessary to identify their strengths and make emphasis on them (Buckingham, 2007).

Moreover, our idea is that there are some basic aspects that motivate or force students to work, and here we rely on the two-factor theory of motivation created by F. Herzberg. It includes two main factors of satisfaction assessment from the work performed: the factors that keep people at work (hygiene factors) and the factors that motivate people to work (motivators) (Herzberg, 1968).

To confirm stated hypothesis in our research we set the goal to identify the actual possibility of Russian students to establish life balance on the basis of their assessment of personal satisfaction and public recognition in studies, at work and in everyday life.

To achieve this goal the following tasks were defined:

1) to examine the peculiarities of life balance among Russian students in conditions of intense activity in studies, at work and in everyday life;

2) to identify the balance in students' studies between their personal assessment of acquired knowledge, nature of teaching, material rewards, etc. and public recognition by other students, professors, university administration, etc.;

3) to determine the balance at students' work between their personal satisfaction from receiving financial independence, acquiring professional skills, benefiting family, etc. and public recognition of these students by colleagues, administration, family, classmates, professors, etc.;

4) to summarize the balance in students' everyday life between their personal satisfaction from creating comfortable living conditions, formation of the basics of modern everyday lifestyle, etc. and their public recognition by hostel administration, roommates, friends, relatives, etc.

In the long run, we form a list of our original definitions of the main terms used in the paper:

- The authors define balance as a system of indicators that characterize such a correlation of elements which makes it possible to reach sustainability in constantly changing development of the phenomena.

- The authors of the article suggest considering life balance of a student as a system of indicators (personal satisfaction and public recognition) that characterize such a correlation of elements (three key life spheres study, work and everyday life) which allows him/her to reach sustainable development in life (fruitful activity in terms of basic curriculum, development of efficient professional skills, harmonization of everyday life). In other words, life balance of a student is a combination of balance in studies, at work, and in everyday life including student's personal satisfaction and public recognition which demonstrates such a correlation of his activity in studies, at work, and in everyday life that forms his sustainable and dynamic life development.

- We presume that public recognition is a psychoemotional (public approval or verbal high evaluation) or material (finance and resources) public reaction to a person's talents, successes or merits. It is useful to highlight, in this regard, that a student can receive public recognition from any person surrounding him: for example, from other students and the professors in studies, from colleagues and employers at work, from relatives, neighbours, roommates and hostel administration in everyday life.

- We determine personal satisfaction as a psychoemotional reaction of a person that is a response to the fulfillment of his/her own desires and needs. Personal satisfaction of a student, as a result, is regarded by the authors of the article in terms of three life spheres - study (satisfaction from a successful studying activity), work (satisfaction from fruitful work and material security) and everyday life (satisfaction from harmonization of leisure time and housekeeping).

\section{Methodology}

\subsection{Respondents}

To participate in the research students of the Finance Department of Plekhanov Russian University of Economics (undergraduate students of Economics) were involved. In total, 908 young people were questioned, and they presented their responses to the questions about their life balance, personal satisfaction and public recognition in studies, at work, and in everyday life. 
Age of respondents varied from 17 to 22 years old, the average age was 20.8 years old. National-ethnic nature of the research was quite diverse: in the survey there were representatives of different nations (Russians (mostly), Azerbaijanis, Armenians, Bashkirs, Buryats, Dagestan, Kalmucks, Kyrgyz, Tadzhiks, Tatars, Chechens) and different religions (Christians (67\%), Muslim (32\%), Buddhists - (1\%)). Gender-sensitive research expressed as follows: women $-59 \%$, and men $-41 \%$. This data was provided by the administration of our university in order to increase the level of representativeness of this research.

The majority of respondents are senior students (62\%) because our research concerned the question of students' balance at work, and it was supposed to identify and consider the level of working young people. In this regard, we analyzed therefore only the questionnaires of 245 respondents who gave a positive answer to the first question ("Do you work?"). As a result, all the statistical results in the Tables 1-10 were based on 245 questionnaires. The choice of such approach can be explained by the processes of optimization of higher education in the Russian Federation.

\subsection{Method}

We applied the method of the survey in order to get information about the students' sphere of consciousness. Firstly, it is the students' opinion - whether they get personal satisfaction in key areas of activity or not. Secondly, it is the estimates of reality - in the form of public recognition of their achievements by other people. The essence of the method of the survey came down to our communication with students through questionnaires in the form of question-answer dialogue. Collection of information during the survey took quite a long time (more than a month). We carried out the survey in the groups of students but sometimes we made it individually.

\subsection{Questionnaire}

The administration of Plekhanov Russian University of Economics was initially interested in revealing students' abilities to manage their efforts, possibilities, and time dedicated to study, work and everyday life. It was based, first of all, on the Russian specific trend according to which Russian students tend to combine study and work. As a result, the authors of the article prepared a questionnaire that was tested and received approval of a focus-group made of the university's social scientists.

The questionnaire contains 45 questions and consisted of 4 sections aimed at examining the students' life balance on the whole as well as the examination of life balance in studies, at work, and in everyday life separately. Each section consisted of questions that helped to understand personal satisfaction of students throughout their life and value judgments about public recognition of their actions.

\section{Results}

Table 1 shows the number of indicators associated with getting personal satisfaction and public recognition of Russian students in studies.

It turned out that personal satisfaction from studies is received by a little more than a half of Russian students (58\%), other $18 \%$ of respondents do not receive personal satisfaction and $24 \%$ of students found it difficult to reply. At the same time, $45 \%$ of students receive public recognition, $23 \%$ - do not receive it and $32 \%$ - found it difficult to reply. Thus, we discovered that in studies the scope and nature of getting students' personal satisfaction basically corresponds to the nature of value judgments of getting public recognition in this field of activity.

Table 1. The results in acquiring by Russian students personal satisfaction and public recognition in studies (General)

\begin{tabular}{|c|c|c|c|}
\hline Indicator & $\begin{array}{l}\text { Students } \\
\text { who receive (\%) }\end{array}$ & $\begin{array}{l}\text { Students } \\
\text { who do not receive (\%) }\end{array}$ & $\begin{array}{l}\text { Students who found it } \\
\text { difficult to reply (\%) }\end{array}$ \\
\hline $\begin{array}{l}\text { Personal satisfaction } \\
\text { in studies }\end{array}$ & 58 & 18 & 24 \\
\hline $\begin{array}{l}\text { Public recognition } \\
\text { in studies }\end{array}$ & 45 & 23 & 32 \\
\hline
\end{tabular}

Table 2 presents the percentage related to educational process elements that bring students personal satisfaction in studies as well as these elements in which, in their opinion, public recognition in studies appears more clearly. 
We determined that the dominant factor providing the personal satisfaction to Russian students in studies is the high competence and professionalism of professors (85\%). A little less personal satisfaction they get from studying in the top-rated higher school (72\%). Next - gaining of knowledge $(63 \%)$, understanding that they are able to apply this knowledge in practice effectively (59\%), and receiving of an academic scholarship (monthly) $(44 \%)$.

The most significant form of public recognition for Russian students in studies is the praise by the teachers respected in student and scientific communities (79\%). The second place occupies the personal scholarship $(73 \%)$, the third - the approval and attention of the students $(61 \%)$, followed by the recognition by others that the level of student's knowledge matches with his/her marks (45\%), and the respect by others of the high status of the higher school (37\%).

We revealed the interesting fact that students value the approval of a well-respected teacher which is necessary to deserve with persistent daily work is much higher in comparison with personal scholarship payments which are appointed by the university administration. In other words, students value almost equally prestigious and material (scholarships, brand of a higher school) and intangible (approval of a social environment, intellectual growth) aspects of personal satisfaction and public recognition but preference is still given to intangible aspects (about 1.8 times more - in the field of personal satisfaction and half as much - in the field of public recognition).

Table 2. The results in acquiring by Russian students personal satisfaction and public recognition in studies (Divided into sources)

\begin{tabular}{|c|c|c|c|}
\hline Indicator & $\begin{array}{l}\text { Students } \\
\text { who receive }(\%)\end{array}$ & $\begin{array}{l}\text { Students } \\
\text { who do not receive }(\%)\end{array}$ & $\begin{array}{l}\text { Students who found it } \\
\text { difficult to reply }(\%)\end{array}$ \\
\hline \multicolumn{4}{|l|}{$\begin{array}{l}\text { Personal satisfaction } \\
\text { in studies }\end{array}$} \\
\hline Knowledge gaining & 63 & 16 & 21 \\
\hline $\begin{array}{l}\text { High qualification of } \\
\text { professors }\end{array}$ & 85 & 12 & 3 \\
\hline Academic scholarship & 44 & 37 & 19 \\
\hline $\begin{array}{l}\text { Study at the top-rated } \\
\text { higher school }\end{array}$ & 72 & 8 & 20 \\
\hline $\begin{array}{l}\text { Practical efficiency of } \\
\text { applied knowledge }\end{array}$ & 59 & 16 & 25 \\
\hline \multicolumn{4}{|l|}{$\begin{array}{l}\text { Public recognition } \\
\text { in studies }\end{array}$} \\
\hline $\begin{array}{l}\text { Recognition by others of } \\
\text { knowledge level and } \\
\text { marks correspondence }\end{array}$ & 45 & 23 & 32 \\
\hline $\begin{array}{l}\text { Praise by well-respected } \\
\text { professors }\end{array}$ & 79 & 10 & 11 \\
\hline Personal scholarship & 73 & 11 & 16 \\
\hline $\begin{array}{l}\text { Respect by others of the } \\
\text { higher school status }\end{array}$ & 37 & 24 & 39 \\
\hline $\begin{array}{l}\text { Approval of other } \\
\text { students }\end{array}$ & 61 & 28 & 11 \\
\hline
\end{tabular}

Table 3 illustrates the degree of interest of Russian students in obtaining personal satisfaction and public recognition in the process of studying.

Thus, $75 \%$ of Russian students claimed that for them it is important or very important to get personal satisfaction from study, $2 \%$ of students are neutral or not interested in it, and almost a quarter of them said about a low demand in it. Therefore, if, at the same time, turn to the results of Table 1, we can see that the number of students who have an urgent need to get personal satisfaction from educational process is approximately 1.3 times greater than of these who actually receive it. 
In the meantime, $61 \%$ of students are strongly focused on getting public recognition of their academic successes, $33 \%$ - believe that it is not particularly important for them or stay neutral, and $6 \%$-were not able to come up with the reply. Interesting trends were revealed when we correlated indicators of the Table 1 and the Table 3. It was found that the number of students who receive personal satisfaction from learning is approximately 1.3 times less than of those who need it, and the number of students who receive public recognition of their studying activity is approximately 1.3 times less than of those who are anticipating for it. However, the desire to get personal satisfaction from study does not comport with the desire to receive public recognition in this area. Consequently, we realized that in studied students are interested in obtaining personal satisfaction by approximately 1.2 times more than public recognition.

Table 3. The degree of interest of Russian students in acquiring personal satisfaction and public recognition in studies

\begin{tabular}{lccc}
\hline Indicator & $\begin{array}{l}\text { Students with high or } \\
\text { medium degree of interest in } \\
\text { acquiring (\%) }\end{array}$ & $\begin{array}{l}\text { Students with low degree of } \\
\text { interest in acquiring (\%) }\end{array}$ & $\begin{array}{l}\text { Students who found it } \\
\text { difficult to reply (\%) }\end{array}$ \\
\hline $\begin{array}{l}\text { Personal satisfaction } \\
\text { in studies }\end{array}$ & 75 & 2 & 23 \\
$\begin{array}{l}\text { Public recognition } \\
\text { in studies }\end{array}$ & 61 & 33 & 6 \\
\hline
\end{tabular}

Table 4 presents the findings linked with personal satisfaction and public recognition of Russian students at work.

In the course of this research, we found out that approximately 3 out of 4 Russian students get personal satisfaction at work. Meanwhile, $17 \%$ of students do not get personal satisfaction at work and relatively the same percentage of students found it difficult to reply (11\%).

In comparison with personal satisfaction only half of working students (2 of 4$)$ get public recognition at work. The remaining half of young respondents, which is quite a high rate, finds it difficult to project this issue on their lives. It seemed remarkable to us that among the respondents there was not a single student who does not receive public recognition at work.

Table 4. The results in acquiring by Russian students personal satisfaction and public recognition at work (General)

\begin{tabular}{lccc}
\hline Indicator & $\begin{array}{l}\text { Students } \\
\text { who receive (\%) }\end{array}$ & $\begin{array}{l}\text { Students } \\
\text { who do not receive (\%) }\end{array}$ & $\begin{array}{l}\text { Students who found it } \\
\text { difficult to reply (\%) }\end{array}$ \\
\hline $\begin{array}{l}\text { Personal satisfaction } \\
\text { at work }\end{array}$ & 72 & 17 & 11 \\
$\begin{array}{l}\text { Public recognition } \\
\text { at work }\end{array}$ & 50 & 0 & 50 \\
\hline
\end{tabular}

Table 5 demonstrates the percentage of elements that bring students personal satisfaction at work as well as those elements in which, in their opinion, public recognition at work appears more fully.

We discovered that work on a specialty brings the most personal satisfaction for Russian students (82\%). A large percentage of respondents $(72 \%)$ say that the opportunity to benefit your family is one of the most essential sources of personal satisfaction related work. Equal percentage of students $(62 \%)$ receives personal satisfaction at work from having the ability to make independent decisions and from the opportunity to create new goods and intellectual products and provide services. The smallest number of students also derives personal satisfaction from the predictability of the workflow which enables them to generate sustainable employment skills.

Not less engaging results concerning public recognition at work were received. In particular, we defined that for $78 \%$ of students the main indicator of public recognition at work is the recognition of their competence by chief. Relatively high number of respondents believes that public recognition at work comes in the form of recognition by relatives of student's employment as a move into adulthood $(70 \%)$ and their gratitude for financial support $(69 \%)$. In addition, $61 \%$ of respondents find public recognition of their working activity in the approval of 
teachers and students, and only $48 \%$ of students find public recognition in positive assessment of colleagues and other employees.

Table 5. The results in acquiring by Russian students personal satisfaction and public recognition at work (Divided into sources)

\begin{tabular}{|c|c|c|c|}
\hline Indicator & $\begin{array}{l}\text { Students } \\
\text { who receive (\%) }\end{array}$ & $\begin{array}{l}\text { Students } \\
\text { who do not receive (\%) }\end{array}$ & $\begin{array}{l}\text { Students who found it } \\
\text { difficult to reply (\%) }\end{array}$ \\
\hline \multicolumn{4}{|c|}{ Personal satisfaction at work } \\
\hline $\begin{array}{l}\text { Independent } \\
\text { decision-making }\end{array}$ & 62 & 14 & 24 \\
\hline Work on a specialty & 82 & 7 & 11 \\
\hline $\begin{array}{l}\text { Opportunity to create } \\
\text { new goods and provide } \\
\text { new services }\end{array}$ & 62 & 26 & 12 \\
\hline $\begin{array}{l}\text { Predictability of a } \\
\text { workflow }\end{array}$ & 45 & 13 & 42 \\
\hline $\begin{array}{l}\text { Opportunity to act for } \\
\text { family benefit }\end{array}$ & 73 & 4 & 23 \\
\hline \multicolumn{4}{|l|}{ Public recognition at work } \\
\hline $\begin{array}{l}\text { Recognition by relatives } \\
\text { of employment as a } \\
\text { move into adulthood }\end{array}$ & 70 & 12 & 18 \\
\hline $\begin{array}{l}\text { Approval of } \\
\text { employment by } \\
\text { professors and students }\end{array}$ & 61 & 15 & 24 \\
\hline $\begin{array}{l}\text { Appreciation by } \\
\text { colleagues and other } \\
\text { employees }\end{array}$ & 48 & 24 & 28 \\
\hline $\begin{array}{l}\text { Approval by chief of } \\
\text { their competence }\end{array}$ & 78 & 5 & 17 \\
\hline $\begin{array}{l}\text { Gratitude of family for } \\
\text { financial support }\end{array}$ & 69 & 12 & 19 \\
\hline
\end{tabular}

Table 6 shows the degree of interest of Russian students in obtaining personal satisfaction and public recognition at work.

We pointed out that the vast majority of Russian students (89\%) get personal satisfaction from work, and a much smaller percentage of students do not get it (11\%). The situation is similar regarding public recognition at work, where $84 \%$ of respondents receive it and $16 \%$ - do not receive. So, based on the data in the Table 4 , the number of students, who receive personal satisfaction at work and who claimed to be very interested in it, is relatively the same. However, the number of students who receive public recognition at work is almost twice as little than of those who need it strongly.

Moreover, the most striking phenomenon is that the percentage of students who found it difficult to determine the extent of their interest in the matter of personal satisfaction and public recognition is zero. 
Table 6. The degree of interest of Russian students in acquiring personal satisfaction and public recognition at work

\begin{tabular}{lccc}
\hline Indicator & $\begin{array}{l}\text { Students with high or } \\
\text { medium degree of interest in } \\
\text { acquiring (\%) }\end{array}$ & $\begin{array}{l}\text { Students with low degree of } \\
\text { interest in acquiring (\%) }\end{array}$ & $\begin{array}{l}\text { Students who found it } \\
\text { difficult to reply (\%) }\end{array}$ \\
\hline $\begin{array}{l}\text { Personal satisfaction } \\
\text { at work }\end{array}$ & 89 & 11 & 0 \\
$\begin{array}{l}\text { Public recognition } \\
\text { at work }\end{array}$ & 84 & 16 & 0 \\
\hline
\end{tabular}

Table 7 presents the findings about personal satisfaction and public recognition of Russian students in everyday life.

According to the findings of the research, half of the respondents get personal satisfaction in everyday life. One-fifth of the students do not get personal satisfaction in everyday life, and the remaining $30 \%$ of the students find it difficult to define it.

Less noticeable range of opinions is observed in the field of public recognition. It is worth emphasizing that $37 \%$ of respondents said that they receive public recognition in everyday life, and exactly the same percentage of students found it difficult to reply. Besides, $26 \%$ of the students do not receive public recognition in everyday life.

We made a conclusion that in everyday life students are more likely to receive personal satisfaction from their everyday life activities rather than public recognition from it (difference is about 1.4 times correspondingly).

Table 7. The Results in Acquiring by Russian Students Personal Satisfaction and Public Recognition in Everyday Life (General)

\begin{tabular}{lccc}
\hline Indicator & $\begin{array}{l}\text { Students } \\
\text { who receive (\%) }\end{array}$ & $\begin{array}{l}\text { Students } \\
\text { who do not receive (\%) }\end{array}$ & $\begin{array}{l}\text { Students who found it } \\
\text { difficult to reply (\%) }\end{array}$ \\
\hline $\begin{array}{l}\text { Personal satisfaction } \\
\text { in everyday life }\end{array}$ & 50 & 20 & 30 \\
$\begin{array}{l}\text { Public recognition } \\
\text { in everyday life }\end{array}$ & 37 & 26 & 37 \\
\hline
\end{tabular}

Table 8 systematizes data describing aspects of everyday life that bring personal satisfaction to Russian students and the students' opinion about what public recognition in everyday life means.

We identified and believe it is necessary to highlight that the greatest impact on the formation of students' personal satisfaction in everyday life is related to matching with the modern everyday lifestyle (86\%). The aspect of availability of the individual accommodation plays a little less role (79\%), followed by the opportunity to manage living conditions for private life $(67 \%)$ and the opportunity to distract from their problems (64\%). It is surprising that the smallest number of students receive personal satisfaction, from such a common thing of everyday life as the ability to create comfort at home (45\%).

Public recognition in everyday life, according to the largest number of students (74\%), appears in the positive evaluation of everyday life by all the people around them. Unfortunately, the praise of family members as a form of public recognition in everyday life takes a secondary position. An even smaller role in public recognition gaining in everyday life plays friends' view on the ability to switch over to different types of activities $(51 \%)$, the approval by hostel administration and roommates $(43 \%)$, and positive judgments of groupmates related to everyday life activities of students (35\%). 
Table 8. The results in acquiring by Russian students personal satisfaction and public recognition in everyday life (Divided into sources)

\begin{tabular}{|c|c|c|c|}
\hline Indicator & $\begin{array}{l}\text { Students } \\
\text { who receive (\%) }\end{array}$ & $\begin{array}{l}\text { Students } \\
\text { who do not receive (\%) }\end{array}$ & $\begin{array}{l}\text { Students who found it } \\
\text { difficult to reply (\%) }\end{array}$ \\
\hline \multicolumn{4}{|l|}{$\begin{array}{l}\text { Personal satisfaction } \\
\text { in everyday life }\end{array}$} \\
\hline $\begin{array}{l}\text { Opportunity to distract } \\
\text { from problems }\end{array}$ & 64 & 17 & 19 \\
\hline $\begin{array}{l}\text { Ability to create comfort } \\
\text { of living }\end{array}$ & 45 & 22 & 33 \\
\hline $\begin{array}{l}\text { Availability of personal } \\
\text { accommodation }\end{array}$ & 79 & 16 & 5 \\
\hline $\begin{array}{l}\text { Conformity of everyday } \\
\text { life with modern mode } \\
\text { of life }\end{array}$ & 86 & 4 & 10 \\
\hline $\begin{array}{l}\text { Opportunity to manage } \\
\text { living conditions for } \\
\text { private life }\end{array}$ & 67 & 8 & 25 \\
\hline \multicolumn{4}{|l|}{$\begin{array}{l}\text { Public recognition } \\
\text { in everyday life }\end{array}$} \\
\hline $\begin{array}{l}\text { Friends' recognition of } \\
\text { an ability to switch over } \\
\text { to other activities }\end{array}$ & 51 & 24 & 25 \\
\hline $\begin{array}{l}\text { Approval by hostel } \\
\text { administration or } \\
\text { roommates }\end{array}$ & 43 & 11 & 46 \\
\hline $\begin{array}{l}\text { Positive evaluation of } \\
\text { everyday life by } \\
\text { groupmates }\end{array}$ & 35 & 36 & 29 \\
\hline $\begin{array}{l}\text { Appreciation of the level } \\
\text { of everyday life by all } \\
\text { other people }\end{array}$ & 74 & 6 & 20 \\
\hline $\begin{array}{l}\text { Praise of the results of } \\
\text { everyday life activities } \\
\text { by family members }\end{array}$ & 64 & 12 & 24 \\
\hline
\end{tabular}

Table 9 shows the degree of interest of Russian students in acquiring personal satisfaction and public recognition in everyday life.

We focused on the fact that very few students (about 2 out of 5) are interested in obtaining personal satisfaction in everyday life, even the lower indicator emerged in the field of public recognition (30\%). At the same time, the number of students who get personal satisfaction and public recognition in everyday life (see. Table 7) and the number of students who expect it much (see Table 9) are approximately equal.

In the course of our study it was found out that, in comparison to study and work, in everyday life students have little interest in obtaining personal satisfaction (49\%) and public recognition (67\%). However, the number of students who tend to receive public recognition in everyday life is approximately 1.4 times less than the number of students who tend to receive personal satisfaction in everyday life.

Furthermore, only a small number of students found it difficult to describe the issue, in particular, $7 \%$-in respect of personal satisfaction in everyday life, and only $3 \%$-in respect of public recognition. 
Table 9. The degree of interest of Russian students in acquiring personal satisfaction and public recognition in everyday life

\begin{tabular}{lccc}
\hline Indicator & $\begin{array}{l}\text { Students with high or } \\
\text { average degree of interest in } \\
\text { acquiring (\%) }\end{array}$ & $\begin{array}{l}\text { Students with low degree of } \\
\text { interest in acquiring (\%) }\end{array}$ & $\begin{array}{l}\text { Students who found it } \\
\text { difficult to reply (\%) }\end{array}$ \\
\hline $\begin{array}{l}\text { Personal satisfaction } \\
\text { in everyday life }\end{array}$ & 44 & 49 & 7 \\
$\begin{array}{l}\text { Public recognition } \\
\text { in everyday life }\end{array}$ & 30 & 67 & 3 \\
\hline
\end{tabular}

Table 10 describes the achievement of life balance by Russian students in each of the key areas of their life, which are study, work, and everyday life, according to personal, subjective perceptions of the students themselves.

At study only $62 \%$ of young respondents believe that they have established the right balance between its various activities, $36 \%$-were not able to establish such a balance, 2\% - refused to answer. In our opinion, more than a half of the students, who took part in the research, believe that they basically have the skills to find the balance in studies.

We identified that students' working activity is less balanced. Thus, $53 \%$ of Russian students do not believe they were able to optimize time and efforts at work, $22 \%$ of students feel that they were able to achieve balance at work, and $25 \%$ refused to reply.

Activity of students in everyday life is sufficiently balanced. There were $81 \%$ of respondents who noted it. $11 \%$ of the respondents believe that they do not have balance in everyday life activities, and $8 \%$ of respondents found it difficult to reply. Our statistics characterizes that about 4 out of 5 students have sufficient skills to organize their everyday life.

Table 10. The results of achievement of life balance by Russian students in studies, at work and in everyday life

\begin{tabular}{lccc}
\hline Indicator & $\begin{array}{l}\text { Students who achieved } \\
\text { balance in stated field (\%) }\end{array}$ & $\begin{array}{l}\text { Students who didn't achieve } \\
\text { balance in stated field (\%) }\end{array}$ & $\begin{array}{l}\text { Students who found it } \\
\text { difficult to reply (\%) }\end{array}$ \\
\hline Study & 62 & 36 & 2 \\
Work & 22 & 53 & 25 \\
Everyday life & 81 & 11 & 8 \\
\hline
\end{tabular}

\section{Discussion}

Our research represents a survey of Russian students on their personal satisfaction and public recognition in the key areas of their lives (study, work, and everyday life) and analysis of the survey outcomes in accordance with the primary goal to identify the actual possibility of Russian students to establish life balance on the basis of their assessment of personal satisfaction and public recognition in studies, at work and in everyday life.

In the previous section ("Results") we developed statistical data and organized it in tables basing on the outcomes of students' survey. Analysis of the data allowed us to describe the following findings and formulate the main conclusions of our research which are the following:

\subsection{Students' Balance in Studies}

In studies Russian students get personal satisfaction ("Results", Table 1-58\%) that does not fully comply with public recognition of their studying activities ("Results", Table 1-45\%). Therefore, students receive more personal satisfaction from study rather than public recognition of their study achievements. The degree of interest in obtaining personal satisfaction in learning is also higher ("Results", Table 3-75\%) than their expectations of public recognition in this area ("Results", Table 3-61\%).

1) Students receive personal satisfaction from the gaining of new knowledge in their specialty (direction) ("Results", Table 2-63\%). However, acquired knowledge does not always find public recognition on the part of professors who consider them to be insufficient ("Results", Table 2-55\%). Balance in learning activity of students is characterized by the fact that the personal evaluation of acquired knowledge correlates with that one given by the professor to some extent. 
2) In the process of studying students are primarily guided by the professionalism of professors whose approval brings them personal satisfaction ("Results", Table 2-85\%). In this regard, they make an effort to earn the praise of the most respected teachers and so get public recognition ("Results", Table 2-79\%). As a result of the research, the balance turned out to be so that with a high respect for professors' professionalism students in their attempts do not convert the educational process to a race for their approval. In other words, we are developing quite the popular view that the behavior of professors and their style of communication highly dictate the involvement of students in the educational process (Uden et al., 2014).

3) Almost every second student through conscientious attitude to study is eager to earn an academic scholarship which brings him/her personal satisfaction in studies ("Results", Table 2-44\%). If only students deserve recognition of public and university administration, it allows them to earn a personal scholarship which immediately distinguishes them in a small but rather prestigious group of students ("Results", Table $2-73 \%$ ). A discovered that balance between academic and personal scholarships is based on the fact that every student is always trying to understand the level of his/her intellectual ability.

4) Students enter top-ranked universities for their personal satisfaction ("Results", Table 2-72\%). Nevertheless, far less than half of the students, who were not able to withstand the studyload of first higher schools and go to another one, are still looking for schools focusing on the level of public respect ("Results", Table $2-37 \%$ ). So, students try to find the balance between their learning abilities and the status of the university much valued by society. It is supposed that the family plays a crucial role in the establishment of the vital interests of students and wakeup of positive features of their character such as high ability to communicate (Sargent et al., 2014). Thuswise, family members create such a learning-oriented environment that students strive to achieve high levels of study excellence like entering the university with a brand name.

5) In practice, benefit of acquired knowledge was that the students were able to apply it in research work or in public activity (e.g. performance on talk shows, radio and TV) ("Results", Table 2-59\%). The success, in turn, leads to the approval by students ("Results", Table 2-61\%). Also, balance is that students begin to make a distinction between the theoretical and practical knowledge, and, at the same time, actively cultivate their practical part due to the approval by groupmates of their first professional achievements.

\subsection{Students' Balance at Work}

At work Russian students, who are able to combine study with work, get much more personal satisfaction ("Results", Table 4-72\%) than public recognition ("Results", Table 4-50\%). This low percentage of public recognition at work is not caused by management team that appreciates the work of the student at a high level ("Results", Table 5-78\%), but low public recognition from peers and other employees ("Results", Table 5-48\%). Nonetheless, global research practice shows that public recognition is more effective when coming from colleagues who know how the employee is working from day to day and not from his superiors that "allocate a quota of public recognition" (Bersin, 2012).

At the meantime, the degree of students' interest in obtaining personal satisfaction and public recognition is striving for equality ("Results", Table $6-89 \%$ and $84 \%$ ). Moreover, all students understand and are able to characterize accurately for themselves the importance of personal satisfaction and public recognition at work because there were no students who found it difficult to reply ("Results", Table 6-0\%).

1) Due to the fact that the responsibility for making decisions is the basis of employment, working students often get personal satisfaction from such independence ("Results", Table 5-62\%). The knowledge of students about the responsibility for making decisions at work makes their family think of students' fast personal growth ("Results", Table $5-70 \%$ ). In this case, students who do not have enough working experience yet need milestones of what they do right and what is wrong. Hence, the recognition of the students as employees can be considered as a communicative tool that reinforces the most important results of their activity (Heathfield, 2014). The students balance out so that personal responsibility for their actions turns into a source of recognition of relatives of their qualities as employees.

2) Students receive personal satisfaction working on specialty because they are approaching the main goal that is self-realization in the selected specialty ("Results", Table 5-82\%). Prestige of this type of work is determined by rather a significant degree of its recognition on the part of the academic society ("Results", Table 5-61\%). Balance is that students choose a more prestigious work on specialty which is very honorable among professors and groupmates.

3) Labor activity, the purpose of which is creation of something new, brings personal satisfaction to working students ("Results", Table 5-62\%). In addition, the production of goods, services, and intellectual products does 
not go unnoticed by the team ("Results", Table 5-56\%). Balance is shown between the working activity of students and public recognition of their work by colleagues. Such an approach is actively supported by scientific community and is usually correlated with the idea that the modern world provides high competition, and creativity aimed at breaking ground gives a competitive advantage (Wu et al., 2014).

4) Certain prediction of working conditions gives students the opportunity to adapt to them and continue to concentrate on the insight of labor which brings them satisfaction ("Results", Table 5-45\%). At the same time, when students acquire stable skills at work, they try to get the approval by the chief ("Results", Table 5-78\%). Management tends to show their support for the students because they understand the interaction algorithm of personal satisfaction and public recognition: the individual actions of the employee-public recognition - personal satisfaction - the growth of company profit (Harrison, 2009). The balance lies in that the students have adjusted workflow in such a way that, on the one hand, it's possible to learn the technical side of it, and, on the other, to go to the content of it and to improve their skills in the eyes of management.

5) Working students feel to be support to their family as they make financial contribution to it ("Results", Table $5-73 \%)$. At the same time, they receive the gratitude of relatives for financial assistance, and their working activity receives the approval by the family ("Results", Table 5-69\%). Balance includes the following components: on the one hand, students receive personal satisfaction from the economic practicality of their work, and, on the other hand, a positive family response for financial assistance. Separately, we note that the students' willingness to contribute voluntarily, to give, not to take away is formed by the family: role simulation of youngsters' behavior is critical for it (Ottoni-Wilhelma et al., 2014).

\subsection{Students' Balance in Everyday Life}

In everyday life, Russian students get more personal satisfaction ("Results", Table 7-50\%) than public recognition ("Results", Table 7-37\%). Low degree of recognition in everyday life is mainly related to the value judgments of groupmates ("Results", Table 8-35\%). Simultaneously, for students the degree of importance to receive personal satisfaction is also significantly lower ("Results", Table 9-44\%) than to receive public recognition ("Results", Table 9-30\%). Consequently, the low level of real public recognition ("Results", Table 7-37\%) leads to the fact that students will lose the desire to get it in this area.

1) Doing household activity gives students the opportunity to escape from the problems connected with other key areas of life (study and work) ("Results", Table 8-64\%). This ability to switch quickly over to another type of activity creates a positive evaluation by the students' friends ("Results", Table 8-51\%). In this situation, students find a balance not only to gain the approval by their peers but also to take a real break from daily work or problems in studies. After all, household activities include rest, the time for a hobby, without which the work-life balance suffers (Reid, 2013).

2) The ability to create comfort at home raises the sense of personal satisfaction for those students who live in a hostel because they can improve their living conditions at least minimally ("Results", Table 8-45\%). This ability is mainly encouraged by hostel administration (for example, the hostel head) or roommates ("Results", Table $8-43 \%$ ). Balance revealed that the students who are forced to live in a hostel in order to obtain approval by hostel administration automatically convert their well-organized everyday life into a source of personal satisfaction. That is, there is not only a "race for the personal satisfaction" (Pabon, 2014), but also "a race for public recognition".

3) Availability of separate (private or rented apartment) accommodation creates students' sense of personal satisfaction ("Results", Table 8-79\%). But it finds a positive judgment only by groupmates because the other part of students is not seeking independence and wants to live with their parents ("Results", Table 8-35\%). Balance in everyday life from the standpoint of accommodation possession is determined by two aspects. On the one hand, students are striving for living independently (but it is rather expensive), and, on the other hand, tend to live with their parents (but it sometimes causes family disputes). At the same time, source of public recognition of the living conditions are groupmates.

4) Almost every student is committed to achieving a modern style of everyday life: dress well, have innovative gadgets, visit expensive entertainment and recreational events ("Results", Table $8-86 \%$ ). Such a lifestyle is approved by the members of the family and causes envy of all the others which is also a form of public recognition of this lifestyle ("Results", Table 8-74\%). Balance is that the chosen lifestyle of students produced an approving assessment by as many people around them as possible but does not conflict with their sense of personal satisfaction. It should be outlined that the expectation of recognition from people around is caused by the students belonging to several social groups at the same time, in each of which the student plays a social role and tries to achieve a reputable position (Pownall, 2012). 
5) Private life (communication with the opposite sex) is essential for the students, and they are struggling to organize adequate living conditions for building their private life ("Results", Table 8-67\%). A similar situation in many cases is the praise from relatives who see here how serious students treat to planning of their future family ("Results", Table 8-64\%). Students are seeking the balance in everyday life in relation to personal life so, that excessive occupation with the creation of everyday life for personal life does not harm other areas of activity, and, as a result, does not cause the disapproval by relatives.

\subsection{Life Balance of Students in Studies, at Work, and in Everyday Life}

To get a feeling of pleasure in life, a person must have an integrated balanced lifeload (Shanafelt, 2005). Life balance of students is striving to harmony which is built on the basis of the balances in key areas of their life. It should be kept in mind that to young people it is not easy to achieve life balance, and sometimes it can be far from harmonious. Thus, in studies ("Results", Table 10-62\%), work ("Results", Table 10-22\%) and in everyday life ("Results", Table 10-81\%) students are always able to resolve the contradictions between personal satisfaction and public recognition (Table 11).

However, a large studyload impedes students to build a harmonious balance of life in studies ("Results", Table $10-37 \%$ ). The most active part of the students gets a job trying to combine it with their study, these students find it the most difficult to balance their life ("Results", Table 10-53\%). It would seem that when students come from the care of parents, the independent decision of household issues complicates the life prioritization but the research represents the opposite results ("Results", Table 10-81\%).

Success in only one of the key areas of life does not provide effective life balance (Wright, 1986) but may lead to a serious imbalance when students are forced to be deducted from university or leave work. Consequently, the ability to build a life balance effectively determines the success in the development of the personality and career of students in general.

\section{Conclusion}

Thus, we discovered that on the point of personal satisfaction and public recognition in the key areas of life of Russian students (study, work, and everyday life) there is sometimes an imbalance which has a strong negative impact on their personal and professional development. Such an imbalance is often set up due to the mistaken belief that the achievement of the balance in one area of life defines effective balance in the other two. It means that students need to develop the ability to "balance out" on a daily basis to resolve the contradiction between personal satisfaction and public recognition.

Scientific novelty of the research lies in the fact that the following issues were identified: firstly, the peculiarities of life balance in a tense activity in studies, at work, and in everyday life. Secondly, the balance in studies of students between their personal assessments of acquired knowledge, the nature of teaching, material rewards etc. and recognition by other student, faculty, university administration etc. Thirdly, the balance at work of students between their personal satisfaction from receiving financial independence, acquiring professional skills, benefiting family, etc. and public recognition of these students by colleagues, family, groupmates, etc. Finally, the balance in everyday life of students between their personal satisfaction from creating comfortable living conditions, formation of the basics of modern household lifestyle, etc. and their recognition by hostel administration, roommates, friends, etc.

In other words, the goal of the research that was to identify the actual possibility of Russian students to establish life balance on the basis of their assessment of personal satisfaction and public recognition in studies, at work and in everyday life, is achieved, and the hypothesis of the research, that the effective life balance of Russian students is founded on the basis of successful development of their ability to optimize the time and effort in studies, at work, and in everyday life, focusing on personal satisfaction and public recognition, is also confirmed. A lot of our judgments are debatable but, on the whole, they comport with the concepts of foreign researchers in this field (Shanafelt, 2005; Frisch, 2005; Buckingham, 2007; Herzberg, 1968). This research does not fully cover the study of the problem of students' life balance. Accordingly, for successful development of this subject we offer to conduct similar researches in other Russian universities and around the world in the future. Additionally, life balance of students in such areas as creativity, scientific research, social and political activity, volunteering, etc. can be examined. 


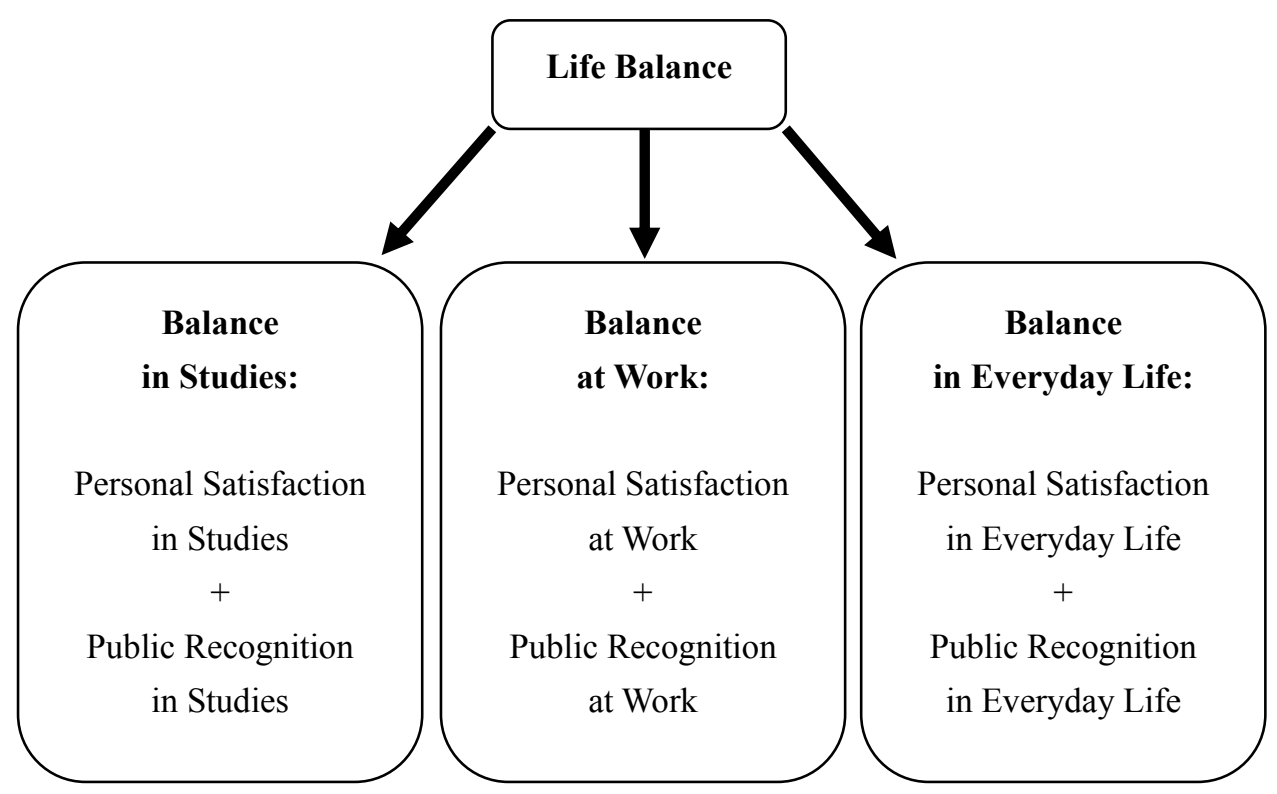

Figure 1. The components of student' life balance in studies, at work and in everyday life

\section{Acknowledgements}

For the support of our research we are grateful to the administration of Plekhanov Russian University of Economics: rector, Doctor of Economics, Professor Victor Ivanovich Grishin \& vice-rector for academic affairs and informatization, Doctor of Economics, Professor Olga Alekseevna Grishina.

\section{References}

Bersin, J. (2012). New research unlocks the secret of employee recognition. Retrieved from http://www.forbes.com/sites/joshbersin/2012/06/13/new-research-unlocks-the-secret-of-employee-recogniti on

Bieg, S., Rickelman, R. J., Jones, J. P., \& Mittag, W. (2013). The role of teachers' care and self-determined motivation in working with students in Germany and the United States. International Journal of Educational Research, 60, 27-37. http://dx.doi.org/10.1016/j.ijer.2013.04.002

Bradford, G. R. (2011). A relationship study of student satisfaction with learning online and cognitive load: Initial results. The Internet and Higher Education, 14(4), 217-226. http://dx.doi.org/10.1016/j.iheduc.2011.05.001

Buckingham, M. (2007). Go put your strengths to work: 6 powerful steps to achieve outstanding performance. New York, NY: Free Press.

Frisch, M. B. (2005). Quality of life therapy: Applying a life satisfaction approach to positive psychology and cognitive therapy. New York, NY: John Wiley \& Sons.

Harrison, K. (2009). Why employee recognition is so important. Retrieved from http://www.cuttingedgepr.com/articles/emprecog_so_important.asp

Heathfield, S. M. (2014). 5 Tips for Effective Employee Recognition. Retrieved from http://humanresources.about.com/od/rewardrecognition/a/recognition_tip.htm

Herzberg, F. (1968). One more time: How do you motivate employees? Harvard Business Review, 46(1), 53-62.

Keller, M. M., Goetz, T., Becker, E. S., Morger, V., \& Hensley, L. (2014). Feeling and showing: A new conceptualization of dispositional teacher enthusiasm and its relation to students' interest. Learning and Instruction, 33, 29-38. http://dx.doi.org/10.1016/j.learninstruc.2014.03.001

Mercer, N. (2012). Explaining the dialogic processes of teaching and learning: The value and potential of sociocultural theory. Learning, Culture and Social Interaction, 1(1), 12-21. http://dx.doi.org/10.1016/j.lcsi.2012.03.001 
Ottoni-Wilhelm, M., Estell, D. B., \& Perdue, N. H. (2014). Role-modeling and conversations about giving in the socialization of adolescent charitable giving and volunteering. Journal of Adolescence, 37(1), 53-66. http://dx.doi.org/10.1016/j.adolescence.2013.10.010

Pabon, E. (2014). What motivates me? Personal satisfaction. Retrieved from http://www.linkedin.com/today/post/article/20140419032740-17487260-what-motivates-me-personal-satisf action

Pownall, I. (2012). Student identity and group teaching as factors shaping intention to attend a class. The International Journal of Management Education, 10(2), 61-74. http://dx.doi.org/10.1016/j.ijme.2012.03.002

Reid, M. (2013). How to find personal satisfaction when you hate your job. Retrieved from http://work.chron.com/personal-satisfaction-hate-job-20654.html

Richardson, J. T. E. (2013). Approaches to studying, conceptions of learning and learning styles in higher education. Learning and Individual Differences, 288-293. http://dx.doi.org/10.1016/j.lindif.2010.11.015

Sargent, T., Kong, P., \& Zhang, Y. (2014). Home environment and educational transitions on the path to college in rural northwest China. International Journal of Educational Development, 34, 98-109. http://dx.doi.org/10.1016/j.ijedudev.2013.05.003

Saunders, R. (2013). Improving student performance through enhanced feedback. The International Journal of Management Education, 12(2), 167-176. http://dx.doi.org/10.1016/j.ijme.2013.02.003

Shanafelt, T. D. (2005). Finding meaning, balance, and personal satisfaction in the practice of oncology. The Journal of Supportive Oncology, 3(2), 157-164. Retrieved from http://www.oncologypractice.com/jso/journal/articles/0302157.pdf

Uden, J. M. van, Ritzen, H., \& Pieters, J. M. (2014). Engaging students: The role of teacher beliefs and interpersonal teacher behavior in fostering student engagement in vocational education. Teaching and Teacher Education, 37, 21-32. http://dx.doi.org/10.1016/j.tate.2013.08.005

Wright, R. (1986). How to be successful and satisfied. Retrieved from http://powertochange.com/discover/life/successful-and-satisfied

Wu, H.-Y., Wu, H.-S., Chen, I.-S., \& Chen, H.-C. (2014). Exploring the critical influential factors of creativity for college students: A multiple criteria decision-making approach. Thinking Skills and Creativity, 11, 1-21. http://dx.doi.org/10.1016/j.tsc.2013.09.004

\section{Appendix A}

The questionnaire survey held among students of the Finance Department of Plekhanov Russian University of Economics

Dear student!

Please, fill in the questionnaire survey on your life balance. By sparing us a few minutes you will make your contribution to the development of Russian education.

\section{QUESTIONNAIRE SURVEY}

In any way mark the points that characterize your attitude towards life balance and balances in stated spheres most precisely.

Do you work?

- Yes

- No

PLEASE, CONTINUE FILLING IN THE QUESTIONNAIRE ONLY IF YOUR ANSWER TO THE FIRST QUESTION IS “YES”!

\section{Part I. LIFE BALANCE}

1. Do you think you've managed to establish balance in your studies?

- Yes

- No

- $\quad$ Find it difficult to reply 
2. Do you think you've managed to establish balance at your work?

- Yes

- No

- $\quad$ Find it difficult to reply

3. Do you think you've managed to establish balance in your everyday life?

- Yes

- No

- $\quad$ Find it difficult to reply

Part II. BALANCE IN STUDIES

4. Do you receive personal satisfaction from the process of studying?

- Yes

- No

- $\quad$ Find it difficult to reply

5. Do you receive public recognition in the process of studying?

- Yes

- No

- $\quad$ Find it difficult to reply

6. Do you receive personal satisfaction from gaining knowledge in the process of studying?

- Yes

- No

- $\quad$ Find it difficult to reply

7. Do you receive personal satisfaction from the high qualification of your professors?

- Yes

- No

- $\quad$ Find it difficult to reply

8. Do you receive personal satisfaction from having an academic scholarship?

- Yes

- No

- $\quad$ Find it difficult to reply

9. Do you receive personal satisfaction from studying at the top-rated higher school?

- Yes

- No

- $\quad$ Find it difficult to reply

10. Do you receive personal satisfaction from the practical efficiency of the knowledge you gain?

- Yes

- No

- $\quad$ Find it difficult to reply

11. Is public recognition in studies manifested in the recognition by others of the correspondence of the level of your knowledge with your marks?

- Yes

- No

- $\quad$ Find it difficult to reply

12. Is public recognition in studies manifested in the praise by well-respected professors?

- Yes

- No

- $\quad$ Find it difficult to reply

13. Is public recognition in studies manifested in having a personal scholarship?

- Yes

- No

- $\quad$ Find it difficult to reply

14. Is public recognition in studies manifested in the respect of your higher school by others?

- Yes

- No

- $\quad$ Find it difficult to reply 
15. Is public recognition in studies manifested in the approval of other students?

- Yes

- No

- Find it difficult to reply

16. How much are you interested in receiving personal satisfaction from study?

- High or medium interest

- Low interest

- $\quad$ Find it difficult to reply

17. How much are you interested in receiving public recognition in the process of studying?

- High or medium interest

- Low interest

- $\quad$ Find it difficult to reply

Part III. BALANCE AT WORK

18. Do you receive personal satisfaction from your work?

- Yes

- No

- Find it difficult to reply

19. Do you receive public recognition at work?

- Yes

- No

- $\quad$ Find it difficult to reply

20. Do you receive personal satisfaction from the independent decision-making at work?

- Yes

- No

- Find it difficult to reply

21. Do you receive personal satisfaction from working on your specialty?

- Yes

- No

- Find it difficult to reply

22. Do you receive personal satisfaction from the possibility to create new products and provide new services?

- Yes

- No

- $\quad$ Find it difficult to reply

23. Do you receive personal satisfaction from the predictability of the workflow?

- Yes

- No

- Find it difficult to reply

24. Do you receive personal satisfaction from the ability to benefit your family?

- Yes

- No

- $\quad$ Find it difficult to reply

25. Is public recognition at work manifested in the recognition by relatives of the fact that your employment is a move into adulthood?

- $\quad$ Yes

- No

- $\quad$ Find it difficult to reply

26. Is public recognition at work manifested in the approval of your employment by professors and students?

- Yes

- No

- Find it difficult to reply

27. Is public recognition at work manifested in the positive evaluation by your colleagues and other employees?

- Yes

- No 
- $\quad$ Find it difficult to reply

28. Is public recognition at work manifested in the approval by your employers?

- Yes

- No

- $\quad$ Find it difficult to reply

29. Is public recognition at work manifested in the gratitude of your family for the financial support (salary)?

- Yes

- No

- $\quad$ Find it difficult to reply

30. How much are you interested in receiving personal satisfaction from work?

- High or medium interest

- Low interest

- $\quad$ Find it difficult to reply

31. How much are you interested in receiving public recognition at work?

- High or medium interest

- Low interest

- Find it difficult to reply

Part IV. BALANCE IN EVERYDAY LIFE

32. Do you receive personal satisfaction from everyday life activities?

- Yes

- $\quad$ No

- $\quad$ Find it difficult to reply

33. Do you receive public recognition related to your everyday life activities?

- Yes

- No

- Find it difficult to reply

34. Do you receive personal satisfaction from the possibility to distract from other problems in everyday life?

- Yes

- No

- $\quad$ Find it difficult to reply

35. Do you receive personal satisfaction from the ability in creating a comfort of living?

- Yes

- No

- Find it difficult to reply

36. Do you receive personal satisfaction from the availability of personal accommodation?

- Yes

- No

- $\quad$ Find it difficult to reply

37. Do you receive personal satisfaction from the conformity of your everyday life with modern mode of life?

- Yes

- No

- $\quad$ Find it difficult to reply

38. Do you receive personal satisfaction from the opportunity to manage living conditions for your private life?

- Yes

- No

- Find it difficult to reply

39. Is public recognition in everyday life manifested in your friends' recognition of your ability to switch over to other activities?

- Yes

- No

- Find it difficult to reply

40. Is public recognition in everyday life manifested in the approval by the hostel administration or roommates?

- Yes

- No

- $\quad$ Find it difficult to reply 
41. Is public recognition in everyday life manifested in positive evaluation by your groupmates of your everyday life activities?

- Yes

- No

- $\quad$ Find it difficult to reply

42. Is public recognition in everyday life manifested in the appreciation of the level of your everyday life by all other people surrounding you?

- Yes

- No

- $\quad$ Find it difficult to reply

43. Is public recognition in everyday life manifested in the praise by your family members of the results of your everyday life activities?

- Yes

- No

- Find it difficult to reply

44. How much are you interested in receiving personal satisfaction from everyday life activities?

- High or medium interest

- Low interest

- $\quad$ Find it difficult to reply

45. How much are you interested in receiving public recognition related to your everyday life activities?

- High or medium interest

- Low interest

- $\quad$ Find it difficult to reply

\section{Dear student!}

The Chair of Political Science and Sociology, the dean's office of the Finance Department \& Center for Humanitarian Training thank you sincerely for assistance and are sure that the results of such cooperation will make the life of Russian students better!

\section{Appendix B}

The results of questionnaire survey held among students of the Finance Department of Plekhanov Russian University of Economics

Table B1. The results of the questionnaire survey held among students of the Finance Department of Plekhanov Russian University of Economics

\begin{tabular}{cccc}
\hline Question number & $\begin{array}{c}\text { The quantity of chosen } \\
\text { answer options № 1 }\end{array}$ & $\begin{array}{c}\text { The quantity of chosen } \\
\text { answer options № 2 }\end{array}$ & $\begin{array}{c}\text { The quantity of chosen } \\
\text { answer options № 3 }\end{array}$ \\
\hline 1 & 142 & 44 & 59 \\
2 & 110 & 56 & 79 \\
3 & 154 & 39 & 52 \\
4 & 208 & 30 & 7 \\
5 & 108 & 91 & 46 \\
6 & 176 & 20 & 49 \\
7 & 145 & 39 & 61 \\
8 & 110 & 56 & 79 \\
9 & 194 & 25 & 27 \\
10 & 179 & 27 & 39 \\
11 & 91 & 59 & 95
\end{tabular}




\begin{tabular}{|c|c|c|c|}
\hline 12 & 149 & 69 & 27 \\
\hline 13 & 184 & 5 & 56 \\
\hline 14 & 149 & 81 & 15 \\
\hline 15 & 176 & 42 & 27 \\
\hline 16 & 123 & 0 & 122 \\
\hline 17 & 152 & 34 & 59 \\
\hline 18 & 201 & 17 & 27 \\
\hline 19 & 152 & 64 & 29 \\
\hline 20 & 110 & 32 & 103 \\
\hline 21 & 179 & 10 & 56 \\
\hline 22 & 172 & 29 & 44 \\
\hline 23 & 149 & 37 & 59 \\
\hline 24 & 118 & 59 & 68 \\
\hline 25 & 191 & 12 & 42 \\
\hline 26 & 169 & 29 & 47 \\
\hline 27 & 218 & 27 & 0 \\
\hline 28 & 206 & 39 & 0 \\
\hline 29 & 122 & 49 & 74 \\
\hline 30 & 91 & 64 & 90 \\
\hline 31 & 157 & 42 & 46 \\
\hline 32 & 110 & 54 & 81 \\
\hline 33 & 194 & 39 & 12 \\
\hline 34 & 211 & 10 & 24 \\
\hline 35 & 164 & 20 & 61 \\
\hline 36 & 125 & 59 & 61 \\
\hline 37 & 105 & 27 & 113 \\
\hline 38 & 86 & 88 & 71 \\
\hline 39 & 181 & 15 & 49 \\
\hline 40 & 157 & 29 & 59 \\
\hline 41 & 108 & 120 & 17 \\
\hline 42 & 74 & 164 & 7 \\
\hline 43 & 152 & 88 & 5 \\
\hline 44 & 54 & 130 & 61 \\
\hline 45 & 198 & 27 & 20 \\
\hline
\end{tabular}

\section{Copyrights}

Copyright for this article is retained by the authors, with first publication rights granted to the journal.

This is an open-access article distributed under the terms and conditions of the Creative Commons Attribution license (http://creativecommons.org/licenses/by/3.0/). 